DOI: $10.4274 /$ turkderm.47.s12

\title{
Paraneoplastik özellik gösteren reaktif dermatozlar
}

\section{Paraneoplastic importance of reactive dermatoses}

\author{
Algün Polat Ekinci, Meryem Sevinç Elinç Aslan* \\ İstanbul Üniversitesi İstanbul Tıp Fakültesi, Deri ve Zührevi Hastalıklar Anabilim Dalı, İstanbul, Türkiye \\ *T.C. Sağlık Bakanlığı Beykoz Devlet Hastanesi, Dermatoloji Bölümü, İstanbul, Türkiye
}

\section{Özet}

Reaktif dermatozlar infeksiyonlar, inflamatuar hastalıklar, ilaç kullanımı ve maligniteler başta olmak üzere birçok nedenle ortaya çıkabilirler. Böyle bir dermatozla karşılaşan hekimler dermatozu tedavi etmenin yanı sıra altta yatan nedeni araştırmaya da yönelirler. Bu derlemede, reaktif dermatozların paraneoplastik potansiyelleri değerlendirilerek tanı sonrası etyoloji, takip ve tedavide yapılması gerekenler irdelenmiştir. Figüre eritemler (eritem anüler santrifüj, eritema giratum repens, nekrolitik migratuar eritem), nötrofilik dermatozlar (sweet sendromu, piyoderma gangrenozum, subkorneal püstüler dermatoz) ve eritema nodozum ile ilgili güncel literatür gözden geçirilmiştir. (Türkderm 2013; 47: Özel Sayı 2: 69-77)

Anahtar Kelimeler: Paraneoplazi, Sweet sendromu, eritem anuler santrifüj, eritema giratum repens, nekrolitik migratuar eritem subkorneal püstüler dermatoz, eritema nodozum, piyoderma gangrenozum

\section{Summary}

Reactive dermatoses may occur related to many underlying causes including infections, inflammatory diseases, medications and malignancies. In the management of these dermatoses the investigation of underlying cause is crucial besides the therapy of dermatosis. In this review, mainly the paraneoplastic potentials of reactive dermatoses have been evaluated and additionally the etiology, follow-up and treatment have been discussed. Recent literature about figurated erythemas (erythema annulare centrifugum, erythema gyratum repens, necrolytic migratory erythema), neutrophilic dermatoses (Sweet's syndrome, pyoderma gangrenosum, subcorneal pustular dermatosis) and erythema nodosum have been scrutinized. (Turkderm 2013; 47: Suppl 2: 69-77)

Key Words: Paraneoplasia, reactive dermatoses, Sweet syndrome, erythema gyratum repens, necrolytic migratory erythema, erythema annulare centrifugum, subcorneal pustular dermatosis, erythema nodosum, pyoderma gangrenosum

\section{Giriş}

Reaktif dermatozlar Dermatoloji polikliniklerinde sıkça karşılaşılan sorunlar arasında olup sistemik hastalıklarla ilişkiyi de yansıtabildiklerinden ayrı bir öneme sahiptir. Paraneoplastik potansiyeli olanlar, infeksiyon, inflamatuvar hastalık, ilaç kullanımı gibi diğer nedenlerin ekarte edilmesi sonrası malignite yönünden uygun şekilde araştııımalıdır. Bu yazıda reaktif dermatozların paraneoplastik potansiyelleri ile eşlik edebilen malignitelerle ilgili literatür bilgileri değerlendirilerek dermatozlara yaklaşımdaki önemli noktaların tartışılması amaçlanmıştır.

\section{Sweet sendromu}

Sweet sendromu, ilk olarak 1964 yılında tanımlanmış ve akut febril nötrofilik dermatoz olarak da isimlendirilmiştir ${ }^{1}$. Ateş, akut başlangıçlı ağrılı kırmızı papül, nodül ve plaklar (Resim 1), periferal nötrofilik lökositoz ve histolojik olarak vaskülit bulguları olmaksızın üst dermiste yoğun nötrofilik infiltrasyon ile karakterize hastalıktır2,3. Ateş, halsizlik gibi sistemik belirtilere de neden olabilir. Sweet sendromunun malignite ile birlikteliği ilk olarak Shapiro ve arkadaşları tarafından testis kanserli bir olgu sunumu ile tanımlanmıştır 4 . Sonrasında Sweet sendromunun birçok farklı neoplazinin işareti olabileceği gösterilmiştir. Hastalığın etyolojisi ile

Yazışma Adresi/Address for Correspondence: Dr. Algün Polat Ekinci, İstanbul Üniversitesi İstanbul Tıp Fakültesi, Deri ve Zührevi Hastalıklar Anabilim Dalı, İstanbul, Türkiye E-posta: algunekinci@yahoo.com 
ilişkilendirilen 3 ana formu bulunmaktadır. Bunlar; klasik ya da idyopatik Sweet sendromu, malignite ile birliktelik gösteren Sweet sendromu ve ilaca bağlı Sweet sendromudur. Bunların dışında elin nötrofilik dermatozu olarak bilinen lokalize Sweet sendromu da tanımlanmıştır5. Klasik ya da idyopatik Sweet sendromu, sıklıkla kadınlarda ve 30-60 yaşlar arasında görülür. En sık üst ekstremite (Resim 2), baş-boyun bölgesi (Resim 3) ve daha az olarak da gövdede görülen lezyonlar olguların 1/3'ünde tekrarlama eğilimi gösterirler³.

Klasik ya da idyopatik Sweet sendromunun tanı kriterleri Tablo 1'de verilmiştir3:

Bu kriterlerden 2'si (1 ve 2) major, 4'ü $(3,4,5,6)$ minör kabul edilir. Tanı için 2 major ve 2 minör kriterin varlığı gereklidir. Sweet sendromunun tanısında lezyondan yapılan deri biyopsisinin histopatolojik incelemesi önemli bir yer tutar. Yüzeyel dermiste matür nötrofillerin baskın olduğu infiltrasyonun yanısıra, dermal papillalarda ve papiller dermiste ödem görülür. Epidermis normal görünümdedir ve çoğu zaman vaskülit bulunmaz. Sedimentasyon hızı artışı çok yüksek de olabilir.

ilaca bağlı Sweet sendromu, en fazla granülosit-koloni stimulan faktör kullanımı sonrası bildirilmiştir3,6. Bununla birlikte daha az olmak üzere birçok farklı ilaçla da ortaya çıktığı görülmüştür. Bu grubun özelliği hastalığın ilacın bırakılması ile düzelmesi ve sistemik provokasyonla tekrarlamasıdır2,7

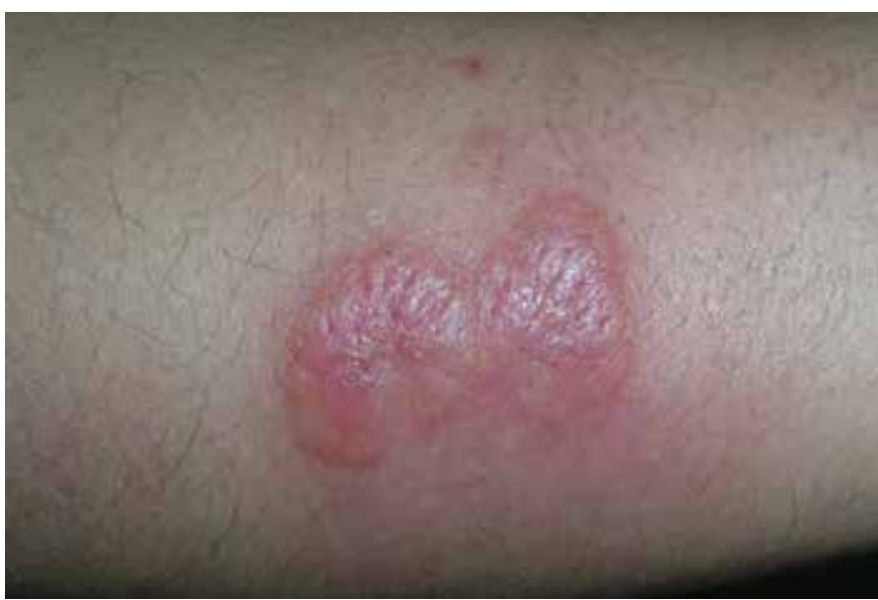

Resim 1. Sweet sendromunun eritemli plak şeklindeki lezyonu

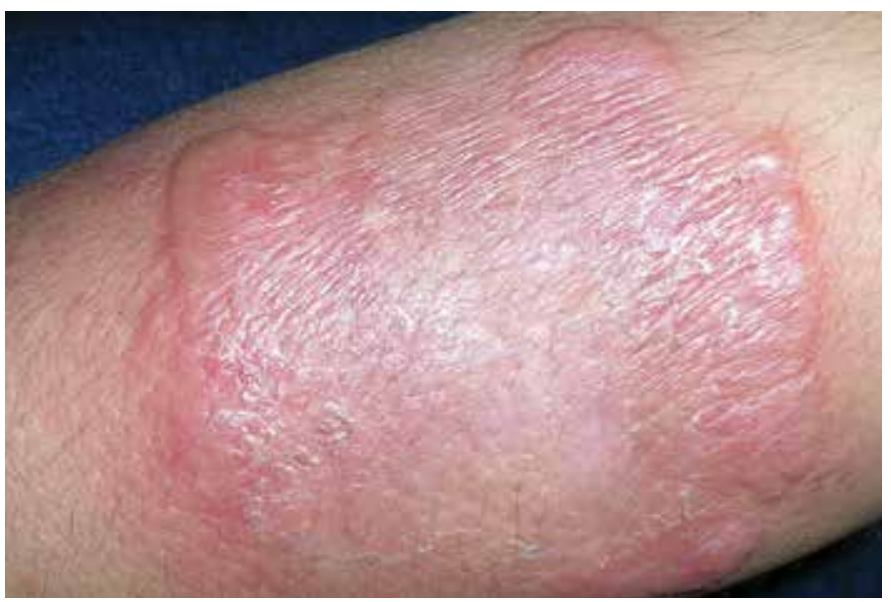

Resim 2. Sweet sendromlu hastada kolda yerleşen eritemli geniş plak
Idyopatik Sweet sendromundan farklı olarak malignite ilişkili Sweet sendromu kadın ve erkeklerde eşit olarak görülmektedir. Sweet sendromu henüz tanı konulmamış bir neoplazinin ilk işareti olabileceği gibi remisyondaki bir tümörün nüks habercisi de olabilir. Sweet sendromunun etyolojisinde malignite görülme sıklığı ile ilgili net bir veri olmamakla beraber \%10-20 arasında bildirilmektedir8. Ancak ülkemizden Bilgili ve arkadaşları tarafından yapılan çalışmada 31 Sweet sendromlu olgu değerlendirilmiş ve sadece birisinde malignite ilişkisi saptanmıştır8. Literatürde bildirilen malignite ilişkili Sweet sendromlularının \%85'i hematopoietik neoplazi ve \%15'i de solid malignitelerle birliktedir7. Bu hastalardaki Sweet sendromunun önemli bir karakteristiği olguların 2/3'ünden fazlasında nüks etmesidir. Hastalık klasik bulguları ile ortaya çıkabildiği gibi alışılmamış klinik ve laboratuvar tabloları görülebilir. Paterji fenomenine uyan reaksiyonlar, periferik kanda nötropeni ve akut myeloid lösemi hastalarında fasial selülit benzeri görünüm bildirilmiştir7,9 .

Akut myeloid lösemi Sweet sendromuna en sık eşlik eden hematopoietik malignite olup bunun dışında; myeloproliferatif hastalıklar (kronik myelositik lösemi, trombositopeniler, polisitemia vera), paraproteinemiler (multipl myelom, önemi bilinmeyen monoklonal gamopatiler), kronik lenfositik lösemi, myelodisplastik sendromlar (aplastik anemi, Fanconi anemisi) ile de birlikteliği bildirilmiştir10-13. Ancak Sweet sendromu servikal, özefagial, gastrik, akciğer, oral, prostat, mesane ve testiküler kanser başta olmak üzere tüm solid kanser tiplerine de eşlik edebilir7,14-18

Hematolojik malignitesi olan, örneğin lösemili bir hastada Sweet sendromu görüldüğü zaman 3 olasılık düşünülmelidir; paraneoplastik bir durum olarak ortaya çıkmış olabilir, hastanın kullanmakta olduğu ilaca bağlı bir dermatoz olabilir ya da kutane lösemi ile eşzamanlı oluşan bir Sweet sendromu lezyonu olabilir. Bu olasılıklardan üçüncüsünde lezyonlarda histolojik olarak Sweet sendromunun matür polimorf çekirdekli lökositlerinin yanı sıra kutane löseminin atipik nötrofilleri bulunmaktadır2,3.

Deri dışı tutulum Sweet sendromundaki önemli bir klinik tablodur. Bu durum özellikle maligniteye eşlik eden Sweet sendromu olgularında bildirilmiştir. Göz, nöromusküler sistem, eklemler, böbrekler, akciğerler, kalp ve karaciğer en sık tutulan deri dışı organ ve sistemlerdir7. Özellikle nörosweet olarak tanımlanan başağıısı, konvülziyonlar, ensefalit, hemiparezi, polinöropati tablosu ile aseptik menenjit, ensefalit,

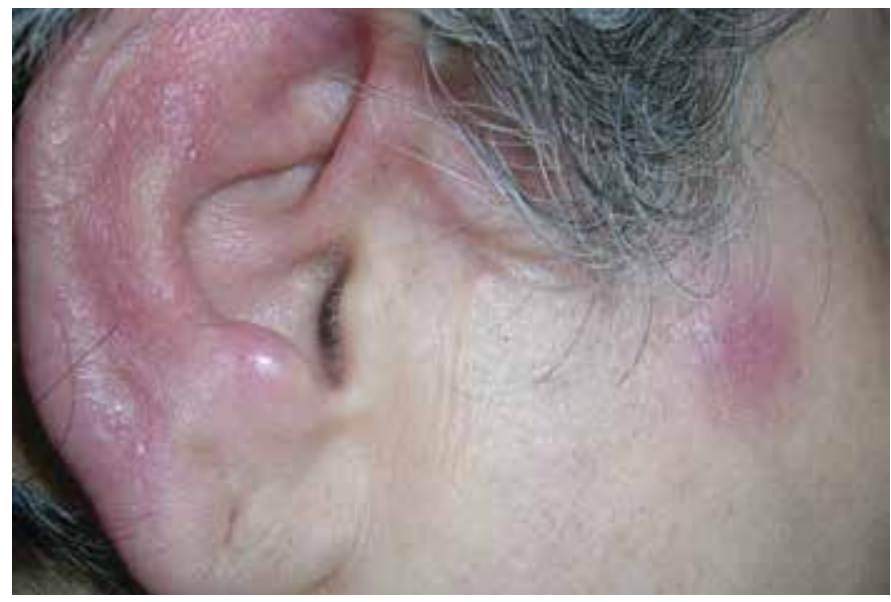

Resim 3. Sweet sendromlu hastada kulak ve yüz lezyonları 
Guillain-Barre sendromu, idyopatik progresif sensorinöral işitme kaybı ve psikiyatrik semptomlar bildirilmiştir19. Deri dışı tutulumun altta yatan hastalık ile ilişkisi bilinmemektedir.

Cohen ve Kurzrock tarafından özellikle altta yatan malignite olasılığ olan Sweet sendromlu hastalarda uygulanmak üzere aşağıdaki tarama protokolü önerilmiştir12. Bunlar;

1. İlaç öyküsünün ayrıntılı irdelenmesi,

2. Tiroid, lenf nodu, oral kavite, deri muayenesi, dijital rektal muayene, erkeklerde prostat ve testis muayenesi, kadınlarda pelvik ve meme muayenesi,

3. Karsinoembriyonik antijen düzeyi, tam kan sayımı, kan biyokimyası, idrar analizi ve kültürü, kadınlarda PAP smear, dışkıda guaiac testi yapılması

4. Diğer testler: Akciğer grafisi, postmenopozal kadınlarda endometrial doku örneklemesi, 50 yaş üzeri tüm hastalarda sigmoidoskopi.

Malignite ile birliktelik gösteren Sweet sendromunda histopatolojik açıdan bazı farklııılar gözlenebilir. Altta yatan hematopoietik neoplazisi olanlarda vaskülit görülebilir2. Yine bu hastalarda inflamatuvar infiltrasyonun karakteri de değişebilmektedir. Lezyonlu deride ayn zamanda lökemia kutis bulguları da olabilir2.

Sweet sendromunda anormal laboratuar bulgusu olarak nötrofilik lökositoz görülse de bu kural değildir ve özellikle akut myeloblastik lösemi hastalarında ciddi nötropeni ve sitopeni olabilir². Dolayısıyla kan tablosu değişikliklerinin olmaması Sweet sendromunun aleyhine değildir.

Tedavide ideal olan, saptanabilirse altta yatan nedenin ortadan kaldırılmasıdır. Malignitenin tedavisi başarılamadığında diğer tedavi seçenekleri gündeme alınır. Tedavide altın standart orta doz sistemik kortikosteroiddir ${ }^{3}$. Ateş ve deri lezyonları saatler içinde gerilese de dozu 2-6 haftada yavaşça düşürmek gerekebilir. Dirençli olgularda pulse steroid, lokalize lezyonlarda da topikal ya da intralezyonel steroid etkili olabilir7. Diğer etkili tedavi seçenekleri potasyum iyodür, kolşisin, indometazin, klofazimin, siklosporin ve dapsondur ${ }^{12}$. Bunlar çoğunlukla sık nüks eden veya kortikosteroide dirençli olgularda denenirler.

\section{Eritem anüler santrifüj}

Eritem anüler santrifüj (EAS), etyolojisinde çok çeşitli hastalıklar bulunan, ancak daha az sıklıkla maligniteler ile birlikte olabilen reaktif dermatozdur20,21. Figüre eritemlerin en sık görülenidir. Malignite ile ilişkili EAS, lenfoma ve lösemi başta olmak üzere en sık lenfoproliferatif malignitelere eşlik etmektedir. Kadınlarda daha sık görülür. Genellikle malign tümörün tedavisi ile birlikte EAS lezyonları da gerilemekte, altta yatan malignitenin nüks etmesi ile de tekrarlamaktadır22.

EAS, kenarı kabarık anüler (halkasal) eritemli lezyonlar ile karakterizedir (Resim 4). Lezyonlar ürtiker benzeri papüller şeklinde başlar, yuvarlak veya oval bir desen oluşturacak şekilde perifere doğru yavaşça genişlerken merkezden solmaya başlar22 (Resim 5). Genişleme hızı değişken olmakla beraber genellikle 2-3 mm/gün olup, 2 haftada 6-8 cm çapa ulaşabilir. Lezyon büyürken kenarında ince bir skuam bırakabilir. Lezyon sayısı nadiren tek ya da çok sayıda (Resim 5) olabilir, ama genellikle birkaç adettir. Altta yatan hastalıkla da ilişkili olarak birkaç gün, hafta ya da nadiren birkaç ay kaldıktan sonra spontan olarak kaybolur. En sık yerleşim yeri gluteal bölge, bacaklar ve kollar olmakla beraber vücudun her yerinde görülebilmektedir22,23.
EAS her yaş grubunda ortaya çıkabilse de genç erişkinlerde daha sıktır. EAS'nin yüzeyel ve derin olmak üzere 2 tipi tanımlanmıştır. Yüzeyel formun genellikle skuamlı bordürü bulunur ve kaşıntılıdır. Derin EAS ise indüre ve skuamsız kenarlı olup kaşıntı nadirdir22,23.

Histopatolojik olarak lenfohistiyositik perivasküler infiltrasyon her iki EAS formunda da görülmektedir. Yüzeyel formda akantoz, spongiyoz, parakeratoz, epidermal hiperplazi, papiller dermiste ödem ve perivasküler infiltrasyon daha belirgin bulgulardır. Öte yandan derin EAS'da orta ve derin dermiste karakteristik olarak manşon tarzında perivasküler infiltrasyon saptanır22.

EAS etyolojisinde çok sayıda neden üzerinde durulmaktadır. Infeksiyonlar (bakteriyel, fungal, viral, parazitik, mikobakteriyel), ilaçlar (salisilatlar, antibiyotikler, antimalaryaller, simetidin gibi), endokrin hastalıklar, gebelik ve sistemik hastalıklar EAS'yi tetikleyebilir22,24,25. Ayrıca lenfoproliferatif ve solid maligniteler EAS'ye eşlik edebilmektedir. Bu şekilde ortaya çıkan EAS lezyonlarının kayboluşu da sıklıkla malignitenin seyri ile uyumludur22.

Chodkiewicz ve Cohen tarafından dünya literatürü taranmış ve EAS'ye eşlik eden malignitesi olan 40 olgu bulunmuştur22. Bu neoplazilerin $\% 62,5^{\prime}$ inin lenfoproliferatif, \%37,5'inin solid tümörler olduğu belirtilmiştir22. Lösemi ve lenfoma 11'er hastada saptanarak EAS ile en sık ilişkili maligniteler olarak tanımlanmışlardır22,26-32. Solid tümörler

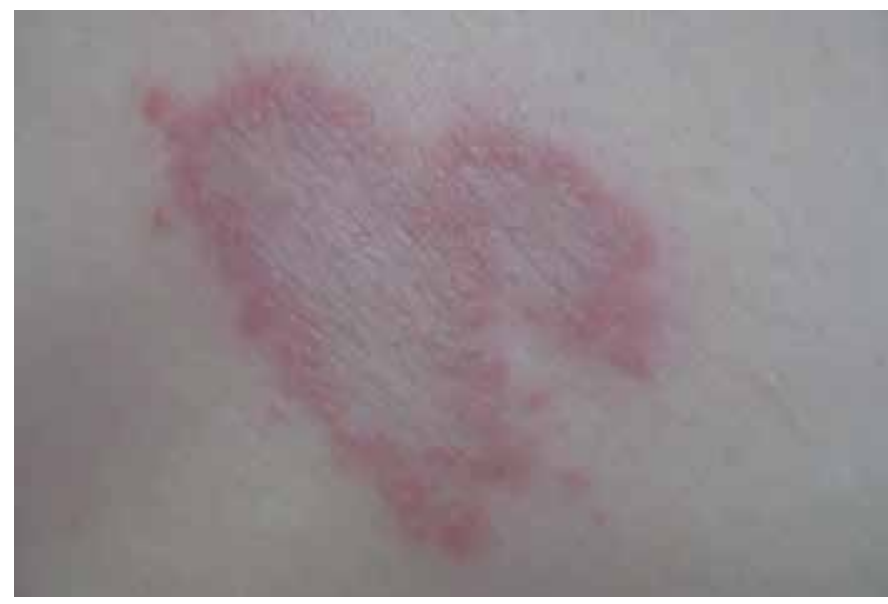

Resim 4. Eritem anüler santrifüjun tipik anüller şekilli, eritemli plakları

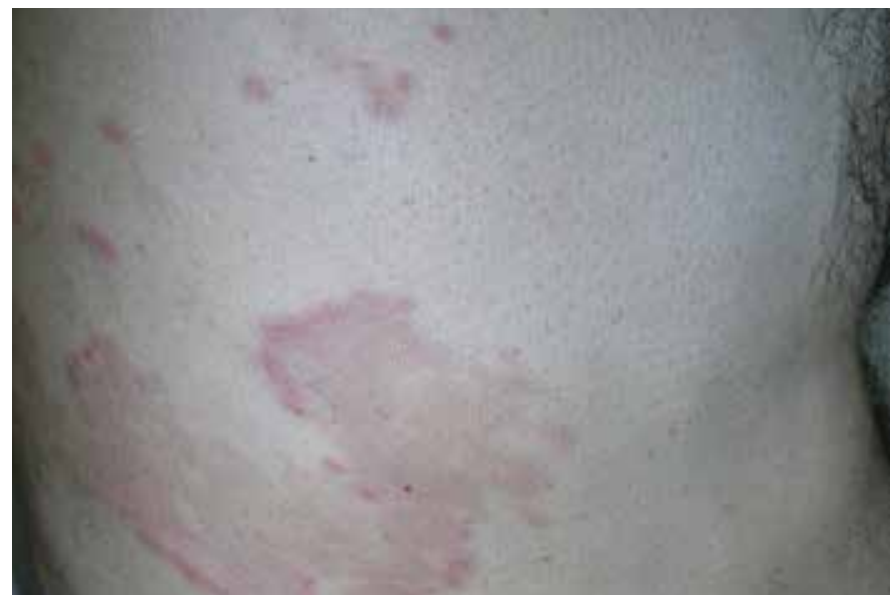

Resim 5. Eritem annüler santrifüj; yaygın anüler plaklar 
ise akciğer kanseri (5 olgu), meme kanseri (2 olgu), gastrointestinal kanserler (3 olgu), prostat kanseri (2 olgu), peritoneal kanser (1 olgu), nazofarengeal kanser (1 olgu) ve karsinoid tümör (1 olgu) olarak belirtilmiştir22,33-38. Bu 40 olgunun yaş ortalaması 55 olup \%64'ü kadındır. EAS lezyonlarının en sık yerleştiği alan ekstremiteler olarak saptanmıştır. Olguların \%46'sında EAS lezyonları malignite tanısından önce ortaya çıkarken, \%33'ünde eş zamanlı, \%21'inde ise neoplaziden sonra saptanmıştır22. Ülkemizden prolaktinomaya eşlik eden bir EAS olgusu bildirilmiştir39.

Chodkiewicz ve Cohen tarafından yapılan bu çalışmada izlem bilgilerine ulaşılabilen 22 hasta değerlendirilmiş, 6 hastanın malignitesi nedeniyle kaybedildiği, 11 hastanın EAS lezyonlarının altta yatan malignitenin tedavisi ile gerilediği, 3 kronik lenfositik lösemi hastasının malignitesinin sebat etmesine rağmen EAS lezyonlarının topikal kortikosteroidle gerilediği, 2 hastanın lezyonlarının malignite cerrahisi sonrası ortaya çıktığı belirtilmiştir22. Sadece lenfoproliferatif malignitesi olanlarda EAS lezyonları hastalığın nüksü ile tekrarlarken solid tümörlerde bu gözlenmemiştir22. Literatür bilgileri değerlendirildiğinde EAS ile malignite birlikteliğinin çok sık gözlenmediği ve çok farklı maligniteler ile birlikte olduğu söylenebilir. Bu hastalarda çok ayrıntılı bir malignite taraması yapılıp yapılmaması konusunda belirlenmiş bir protokol da bulunmamaktadır.

Idyopatik olan derin EAS tedavisinde sistemik, yüzeyel olanda ise topikal kortikosteroidler ana tedavi seçeneği olup, lezyonlarda kaşıntı varsa sistemik antihistaminikler de kullanılmaktadır. Paraneoplastik EAS lezyonlarında ise iyileşmenin altta yatan malignitenin tedavisi ile de sağlanabildiği gösterilmiştir. Öte yandan malignitenin tedavisine rağmen EAS'nin bağımsız bir seyir gösterdiği olgular da bildirilmiştir22

\section{Nekrolitik migratuvar eritem}

Nekrolitik migratuvar eritem (NME) sıklıkla, glukagon salgılayan pankreas adacık hücre tümörü olan glukagonoma ile birliktelik gösteren paraneoplastik bir hastalıktır 40 . NME nadir görülen figüre eritemler arasında yer alır ancak ortaya çıktığında çoğunlukla bir tümör göstergesi olduğu düşünülür. Multifaktöryel malnutrisyon denilen çinko, aminoasitler ve esansiyel yağ asitleri kombinasyonunun azalmas tablosunun, deride inflamasyona yol açan araşidonik asit üretimini artırması NME patogenezinde kabul gören en olası hipotezdir41.

NME, glukagonoma ya da glukagon salgılayan tümörler için patognomonik kabul edilmekle beraber karaciğer hastalığı, malabsorbsiyon bozuklukları, adacık dışı hücre tümörlerinde de bildirilmiştir42. NME'ye eşlik eden diğer maligniteler psödoglukagonoma sendromuna yol açan tümörler olup küçük hücreli akciğer kanseri, karaciğer kanseri, insülin sekresyonu yapan tümörler ve duodenal neoplazmlardır43-44. Döküntü sıklıkla perioral ya da inguinal alandan başlar. Başlangıçta düzensiz sınırlı, kavisli ya da polisiklik paternde pembe-kırmızı makülopapüler döküntü şeklindedir. Ancak üzerinde gevşek büller gelişir ve bunlar kolayca açlıp krutlanırken lezyon kenarında yeni vezikül oluşumu devam eder42,45,46.

NME' de histolojik bulgular özgün değildir ve hastalığın derecesine göre değişkenlik gösterir. Ödem, bazal hücre hiperplazisi, düzensiz akantoz, lenfositten zengin perivasküler infiltrasyon, yüzeyel nekroz gösteren vakuollü epidermal hücreler ve parakeratoz görülebilir39,45.

NME tedavisinde temel yaklaşım altta yatan nedenin ortadan kaldırımasıdır. Öte yandan glukagon salınımını inhibe eden oktreotid tedavisi yanısıra aminoasit ve yağ asiti infüzyonları 47 ile de deri lezyonlarında başarılı sonuçlar alınmaktadır 48 .

\section{Eritema giratum repens}

Eritema giratum repens (EGR) nadir bir figüre eritem tipi olup ilk olarak meme kanserli bir hastada tümör tanısından önce ortaya çıkışı ile tanımlanmıştır 39 . Kadınlara oranla erkeklerde daha çok rastlanan hastalık en sık 5-6. dekatlarda görülür. Lezyonlar yaygın, serpijinöz, polisiklik ve kaşıntılı eritem şeklindedir. Lezyon kenarında deskuamasyon bırakarak genişler ve ağaç gövdesi yüzeyi gibi konsantrik bir desen oluşturur45,49,50. El ve ayaklar çoğunlukla korunmuştur ancak bazen palmoplantar hiperkeratoz, iktiyoz ve tırnak bozuklukları görülebilir45,49

EGR'li hastaların \%82'sinde eşlik eden malign tümör saptanmıştır 45 . Bu da altta yatan malignite yönünden çok ayrıntılı bir araştırma yapılmasını zorunlu kılmaktadır. Akciğer kanseri (\%32) en sık eşlik eden malignite olup bunu özefagus (\%8) ve meme (\%6) tümörleri takip etmektedir45,51. Bunlar dışında kolon, mide, mesane, prostat, uterus, rektum, pankreas kanserleri ve multipl myelomla da birlikteliğ bildirilmiştir39.

EGR'nin histopatolojisi özgün değildir. Hiperkeratoz, parakeratoz, akantoz ve spongiyozla birlikte dermiste perivasküler lenfositik infiltrasyon bulunur39,52. Fizyopatolojisi tam olarak bilinmeyen hastalıkta immun mekanizmaların rol oynadığı düşünülmektedir. Direkt immun floresan incelemede bazal membranda C3 ve/veya IgG depolanması görülebilir39,52.

EGR lezyonları altta yatan malignitenin tedavisi ile haftalar içinde geriler. Dolayısıyla paraneoplastik ilişkj çok belirgindir. Ayrıca immunsupresif ve antihistaminik kullanımına da yanıt veren olgular bildirilmiştir39.

\section{Subkorneal püstüler dermatoz}

Subkorneal püstüler dermatoz (SPD) kronik, tekrarlayıcı özelliği olan püstüllerin baskın olduğu bir hastalıktır. Illk olarak 1956 yılında Sneddon ve Wilkinson tarafından tanımlanmıştı553. Kadınlarda daha sık olmak üzere orta yaş grubunda görülür. Döküntü başlıca gövde (Resim 6 ve 7) ve ekstremite fleksörlerinde yerleşirken palmoplantar alanda nadiren görülür, yüz ve mukozal lezyona ise neredeyse hiç rastlanmaz. Püstüller kendiliğinden iyileşmeye eğilimli olsa da yenileri çıkmaya devam eder. Hastalığın patogenezi tam olarak bilinmemektedir. Akantoliz ve spongiyoz olmadan subkorneal nötrofil birikimi ile steril subkorneal püstül oluşumu en belirgin histolojik özelliğidir. Ancak geç lezyonlarda akantoliz de görülebilir. Klasik SPD'de direkt ve indirekt immunfloresan incelemeler negatiftir 54

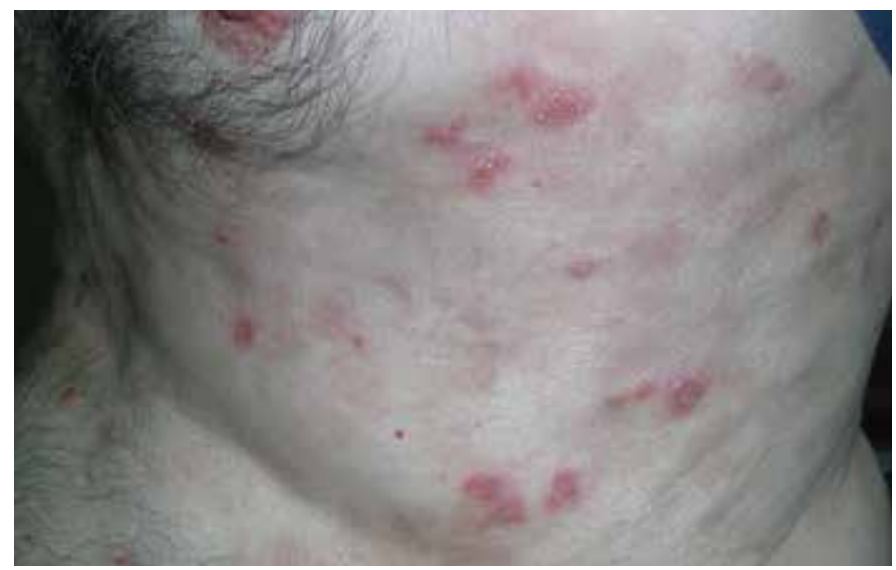

Resim 6. Subkorneal püstüler dermatozlu hastada aksilla ve gövdede püstüler lezyonlar ve gerileyen lezyonların yerinde hiperpigmentasyon 
Hastalığın etyolojisi bilinmemekle beraber benign monoklonal IgA gamopatisi55 ve piyoderma gangrenozum 56 ile birlikteliği iyi bilinmektedir. Her ikisi de SPD tanısından önce ya da sonra gelişebilir. SPD, malignitelere ve özellikle IgA tip multipl myeloma da eşlik edebilmektedir53. Tüm SPD hastalarının altta yatabilecek multipl myelom açısından taranması, serum ve idrarda paraproteinemi yönünden araştırılması önerilmektedir. SPD'ye eşlik ettiği bildirilen diğer maligniteler kronik lenfositik lösemi, metastatik timoma, apudoma ve akciğerin epidermoid karsinomudur54,58-60.

SPD tedavisinde dapson ile başarılı sonuçlar elde edilmektedir. Ancak tedavi uzun sürmekte ve lezyonları kontrol eden dozda ilacı aylarca veya yıllarca kullanmak gerekebilmektedir. Asitretin, etretinat, PUVA, geniş ve dar bant UVB daha nadir kullanılan tedavi seçenekleridir. Myeloma eşlik eden SPD tedavisinde paraproteinemiyi azaltan kemoterapi deri lezyonlarını da düzeltebilmektedir 54 .

\section{Piyoderma gangrenozum}

Piyoderma gangrenozum (PG) nadir görülen, kronik seyirli, isminden farklı olarak infeksiyöz olmayan, inflamatuvar nötrofilik dermatozdur61-64. PG tipik olarak ağrılı bir nodül veya püstül ile başlayıp, hızlı ilerleyen, sınırları belirlenemeyen, kenarları deriden kabarık, menekşe moru renginde, dokunmakla hassas, mukopürülan veya hemorajik eksudalı, geniş deri ülserleri ile karakterize olur (Resim 8)63,65,66. Nedeni tam olarak bilinmemekle beraber, anormal nötrofil kemotaksisinin patogenezden primer sorumlu olduğu düşünülmektedir67.

PG özellikle 20-50 yaşlar arasında olmak üzere genç ve orta yaşlı erişkinlerde ve erkeklere göre kadınlarda daha sık görülür64,68-73. Genel insidansı yılda 3-10 milyonda birdir70,73. En sık gövde ve ekstremitelerde yerleşmektedir. Atipik bölgeler olarak baş ve boyun, genital bölge nadiren tanımlanmıştır73.

Powell ve arkadaşları ${ }^{4}$ PG'yi klinik olarak ülseratif, büllöz, püstüler ve vejetatif tip olmak üzere 4 ana grupta sınıflandırmışlardır. Her bir grupta klinik ve histolojik görünüm, progresyon hızı, ilişkili olduğu hastalıklar ve tedavi seçenekleri farklılıklar göstermektedir.

En sık rastlanan ülseratif form genellikle alt ekstremitelerde ve gövdede, kenarları kabarık ve dekole, mukopürülan ülserler şeklinde görülür. İyileşen lezyonların yerlerinde sikatris kalır (Resim 9).

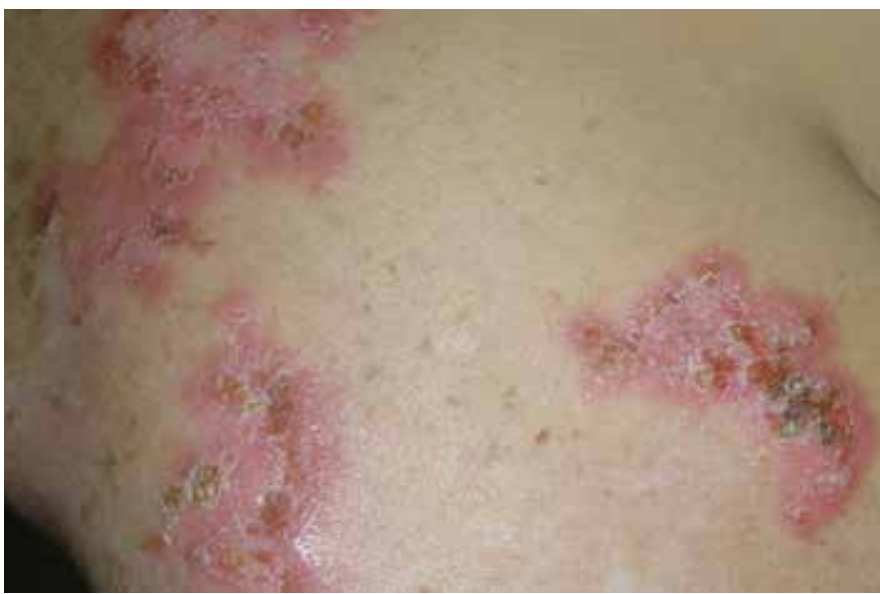

Resim 7. Subkorneal püstüler dermatozda gövdede yerleşen, eritemli zeminde püstüller ve püstüllerin açılmasıyla oluşan krutlar şeklinde tipik görünüm
Sıklıkla romatolojik hastalıklar, inflamatuvar barsak hastalıkları ve monoklonal gamopatilerle ilişkili olabilir74-78. Püstüler form ise sıklıkla inflamatuvar barsak hastalıkları ile ilişkili olup, etrafı eritemli halo ile çevrili multipl steril, simetrik püstüllerle karakterizedir62,64,73. Büllöz PG'de ağrılı büller zemininde ortaya çıkan ülser daha yüzeyel ve daha az destrüktifdir. Daha çok hematolojik malignitelerin seyri sırasında ortaya çıkması açısından önem taşır61,62,64,73. Vejetatif PG (yüzeyel granülomatöz piyoderma) lokalize, yavaş genişleyen, agresif olmayan, genellikle ağrısı, verrüköz ve ülseratif lezyonlarla karakterizedir64,73. Daha çok baş-boyun bölgesine yerleşir ve çoğunlukla sistemik bir hastalıkla birlikteliği yoktur73

PG'nin etyolojisi tam olarak bilinmemektedir62,73. Ancak hastaların yaklaşık yarısında altta yatan sistemik bir hastalık vardır63,73,74. Bunların başlıcaları inflamatuar barsak hastalıkları, artrit, lösemi, hepatit, primer biliyer siroz, internal malignite ve monoklonal gamopati, lösemi, lenfoma ve myelodisplastik sendrom gibi lenfoproliferatif hastalıklardır72-75,79 (Tablo 2). PG'li olguların \%7'si malignitelerle ilişkili bulunmuştur. Bununla birlikte hastalık atipik varyantıyla ortaya çıkarsa malignite ile ilişkisi \%27'lere kadar yükselebilir71. En sık ilişkili olduğu malignite akut miyeloid lösemidir. Bunu multipl myelom ve kolorektal kanserler izler 71 .

PG tanısı, karakteristik deri lezyonlarının varlığına ve olası diğer hastalıkların dışlanmasına dayanır62,63,74,75. Lezyondan biyopsi

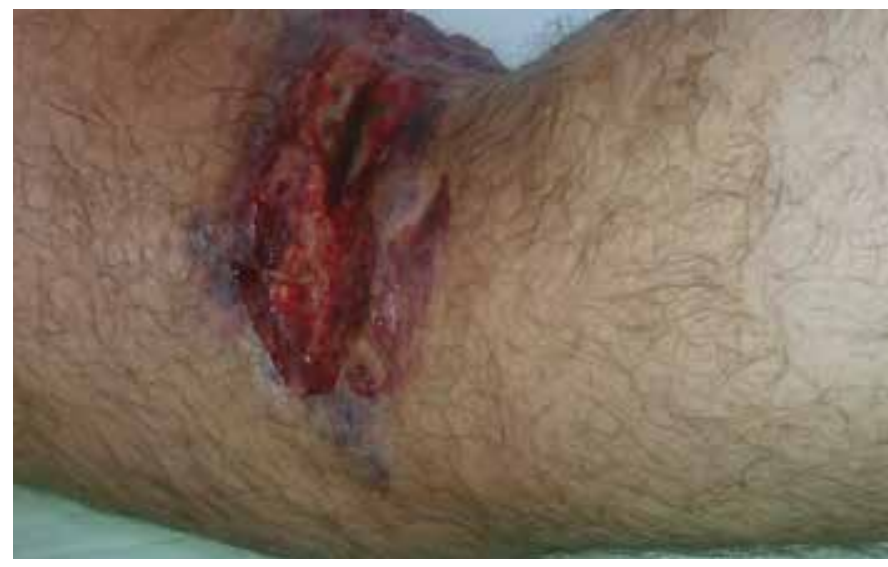

Resim 8. Ülseratif piyoderma gangrenozum

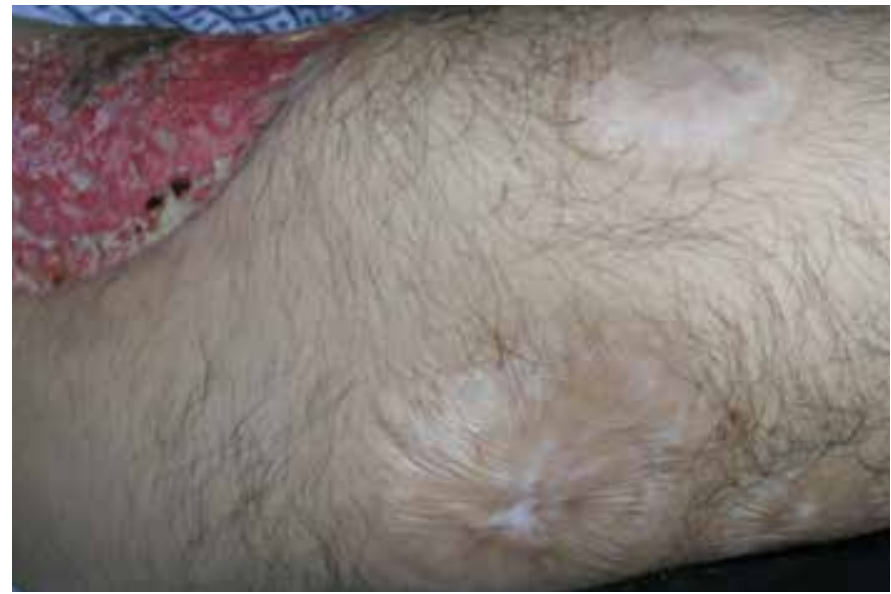

Resim 9. Piyoderma gangrenozumun gerilemiş lezyonlarına ait skatris ve aktif ülser bir arada gözükmektedir 
ve kültür incelemesi yapılmalıdır. Histopatolojik görünüm özgün olmasa da nötrofillerin baskın olduğu inflamatuvar infiltrasyon tanıyı destekleyebilir. PG tanısında iki hedef vardır: birincisi, ülserasyonun diğer nedenlerinin dışlanması, ikincisi ise ilişkili olabilecek bir sistemik hastalık varlığının saptanmasıdır. Bazı çalışmalarda majör ve minör tanı kriterleri tanımlanmıştır. Buna göre 2 majör ve en az 2 minör kritere sahip hastalara PG tanısı konabilmektedir72,79 (Tablo 3). Hastaların \%30' unda paterji fenomeni pozitifdir.

Laboratuar bulguları, eşlik eden hastalığın belirtilerini yansıtabilir. PG'li hastalarda hemogram, rutin biyokimya, böbrek ve karaciğer fonksiyonları, serum protein elektroforezi, tiroid hormonları, kriyoglobulinler, VDRL, otoantikorların varlığı araştırılmalıdır. Taramaya yönelik olarak ayrıca kemik iliği incelemesi, akciğer grafisi, gastrointestinal kanal kontrastlı incelemesi, anjiografi ve doppler USG

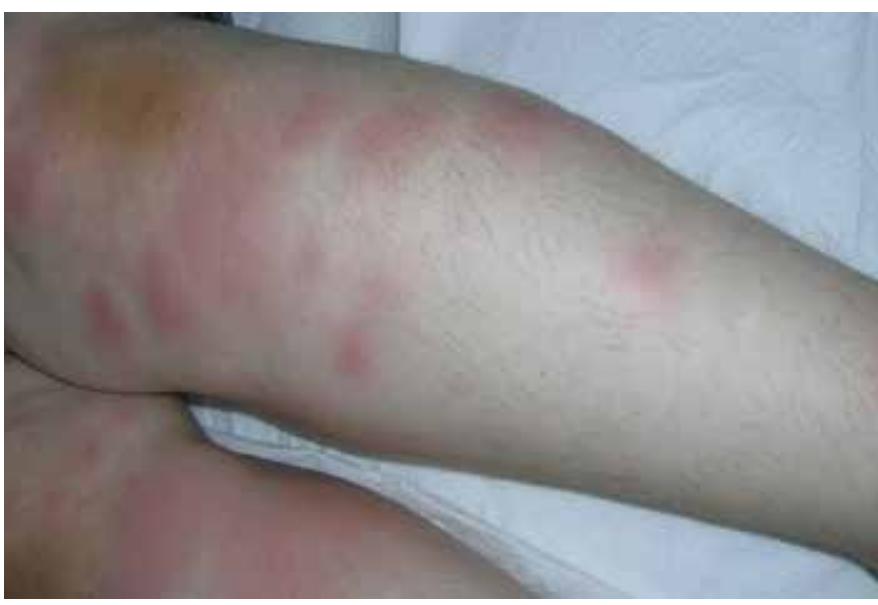

Resim 10. Eritema nodozum; pretibial bölgede yerleşen yüzeyi eritemli subkutan nodül ve plaklar yapılabilir62,69,74,76. Sıklıkla lökositoz, yüksek eritrosit sedimentasyon hızı ve C-reaktif protein düzeyi saptanır, anemi ve düşük serum demiri, hiper veya hipoglobulinemi bulunabilir 73

Günümüzde PG tedavisi için altın bir standart veya kabul edilmiş bir tedavi şeması yoktur. Tedavi lezyonun boyutu, büyüme hızı, yeni lezyonların oluşumu, eşlik eden hastalığın varlığı ve hastanın genel durumu gibi birçok faktör göz önüne alınarak yapılmalıdır73,80. Amaç ülserdeki inflamatuvar olayı baskılamak, ağrıyı azaltmak ve en az yan etkiyle altta yatan hastalığı kontrol altına almaktır. Sistemik bir hastalıkla ilişkili olmayan hafif formlarda topikal tedaviler tercih edilir. Ancak altta yatan bir hastalık saptanan olguların tedavisinde, sistemik hastalığın tedavisi ile $P G^{\prime}$ de de düzelme sağlanabileceğinden sadece PG değil, eşlik eden sistemik hastalık da hedef alınmalıdır73.

Topikal tedavide güçlü etkili veya intralezyonel (ülser kenarına) kortikosteroidler, kalsinörin inhibitörleri, nitrojen mustard, sodyum kromoglikat ve 5-aminosalisilik asitin etkili olduğuna dair çalışmalar mevcuttur65,74,81-85

Sistemik tedavide 1-2 $\mathrm{mg} / \mathrm{kg} /$ gün prednizolon, 2-3 $\mathrm{mg} / \mathrm{kg} / \mathrm{gün}$ siklosporin, 200 mg/gün dapson, klofazimin 300-400 mg/gün, 100$150 \mathrm{mg} / \mathrm{gün}$ azatiopirin, $2 \mathrm{gr} / \mathrm{gün}$ mikofenolat mofetil, 0,1mg/kg/ gün takrolimus verilebilir62,64,65,72-75,80,86-88. Diğer tedavi seçenekleri arasında plazmaferez, IVIG, talidomid, kolşisin, siklofosfamid, metotreksat, sülfasalazin yer almaktadır58,61,69,85,86. Son zamanlarda Özellikle inflamatuvar barsak hastalığı ile ilişkili dirençli PG olgularında TNF- $\alpha$ blokerlerinin (infliksimab, etanersept, adalimumab) oldukça başarılı olduğu bildirilmiştir62,65,91-95. Tedavideki son gelişmelere rağmen, PG'li hastaların uzun dönemde sonuçları öngörülememekte, bazı serilerde mortalite oranı \%30 olarak bildirilmektedir. Erkek cinsiyet, ileri yaş ve özellikle hematolojik malignitelerle ilişkili olan büllöz PG tipi kötü prognostik faktörlerdir81.

\section{Tablo 1. Sweet sendromu tanı kriterleri ${ }^{3}$}

1. Ani başlangıçı̆ı ağııı eritemli plak ya da nodüller,

2. Histopatolojik olarak dermiste vaskülit bulguları olmaksızın yoğun nötrofilik infiltrasyon,

3. $38^{\circ} \mathrm{C}^{\prime}$ den yüksek ateş,

4. Altta yatan hematolojik ya da visseral malignite, inflamatuvar hastalık ya da gebelik olması veya üst solunum yolu infeksiyonu, gastrointestinal infeksiyon ya da aşılama ile tetiklenmesi,

5. Sistemik kortikosteroid ya da potasyum iyodür tedavisine çok iyi yanıt alınması,

6. Hastalık sırasındaki laboratuvar değerlerinden 4 parametrenin 3'ünün anormal (eritrosit sedimentasyon hızının 20 mm/saat'ten yüksek olması, C-reaktif protein pozitifliği, lökosit sayısının $>8000 / \mathrm{mm}^{3}$ ve bunun da $>\% 70$ nötrofil şeklinde olması) saptanmasıdır.

Tablo 2. Piyoderma gangrenozum ile ilişkili hastalıklar $72-75,79$

\begin{tabular}{|l|l|}
\hline Gastrointestinal sistem hastalıkları & $\begin{array}{l}\text { Inflamatuvar barsak hastalıkları \%15 (ülseratif kolit, Crohn hastalığı), Divertiküloz, Gastrit, Gastrik ve } \\
\text { duodenal ülserler, Intestinal polipler, Primer biliyer siroz, Kronik aktif hepatit }\end{array}$ \\
\hline Romatolojik hastalıklar & Romatoid artrit, Ankilozan spondilit, Osteoartrit, Polikondrit \\
\hline $\begin{array}{l}\text { Hematolojik } \\
\text { hastalıklar }\end{array}$ & $\begin{array}{l}\text { Akut ve kronik myeloid lösemi, Monoklonal gamopatiler (\%10), Waldenström makroglobulinemi, } \\
\text { Polistemia vera, Lenfoma }\end{array}$ \\
\hline Kollajen vasküler hastalıklar & $\begin{array}{l}\text { Takayasu arteriti, Wegener granülomatozu, Sistemik lupus eritematozus, Nekrotizan vaskülit, } \\
\text { Dermatomyozit }\end{array}$ \\
\hline Solid tümörler & $\begin{array}{l}\text { Kolon kanseri, Mesane kanseri, Prostat kanseri, Meme kanseri, Over kanseri, Akciğer kanseri, Renal } \\
\text { hücreli kanser, Karsinoid tümör }\end{array}$ \\
\hline Diğer & Tiroid hastalıkları, Diyabet, HIV, Sarkoidoz, \\
\hline
\end{tabular}


Tablo 3. Piyoderma gangrenozum tanı kriterleri

\section{Majör Kriterler}

Tipik olarak menekşe renginde, hızlı ilerleyen, sınırları belirsiz, ağrılı nekrotik ülser Ayırıı tanıdaki hastalıkların dışlanması

(venöz ve arteriyel ülserler, vaskülitler)

\section{Minör Kriterler}

Histopatolojik incelemede dermiste nötrofilden zengin

infiltrasyon

İmmünoglobülin veya kompleman veya her ikisinin

depolanması

ilişkili hastalık varlığ

Konvansiyonel tedaviye kısmi yanıt veya yanıtsızlık

Immunsupresyon tedavisine yanıt

\section{Tablo 4. Eritema nodozumun eşlik ettiği maligniteler}

Kolon adenokarsinomu ${ }^{112}$

Karsinoid tümör106

Serviks kanseri113

Hepatoselüler karsinom ${ }^{114}$

Hodgkin hastalığı115

Lösemi116

Akciğer karsinomu117

Non-Hodgkin lenfoma118

Pankreas kanseri107

Renal karsinom ${ }^{119}$

Sarkom 120

Mide kanseri101

\section{Eritema nodozum}

Eritema nodozum (EN), en sık rastlanan inflamatuvar pannikülit tipi olup, tüberküloz, sarkoidoz, inflamatuvar barsak hastalığı, Behçet hastalığı veya malignite gibi birçok önemli sistemik hastalığın ilk belirtisi olabilmektedir96.

Klinik olarak simetrik, deriden kabarık, kırmızı ve sıcak, palpasyonla ağrılı, sınırları net olarak seçilemeyen, 1-10 cm çapında, subkutan nodüller şeklinde izlenir (Resim 10)96-100. En sık pretibial bölgede yerleşmekle birlikte nadir olarak baş-boyun bölgesi, ön kol ekstansör yüzü, uyluk ve gövdede de ortaya çıkabilir96,99,100. Genellikle 3-6 haftada ülserleşmeksizin, atrofi veya skar dokusu bırakmadan kendiliğinden iyileşir 96,98,99. Etyolojiden bağımsız olarak lezyonların başlamasından 1-3 hafta öncesinde iştahsızlık, halsizlik, kilo kaybı, ateş, öksürük ve artralji gibi prodromal semptomlar görülebilir100.

EN'nin insidansı 1-5/100,000'dir96. EN'de yaş ve cinsiyet dağılımı, idyopatik veya sekonder olmasına bağlıdır97. Idyopatik olgular her yaşta görülmekle birlikte genellikle 20-45 yaş arasında ve kadınlarda daha sıktır. Kadın erkek oranı 3-6/1 olarak bildirilmiştir96,97. Etyolojisi bilinen olgularda ise; yaş ve cinsiyet dağılımı EN'ye yol açan hastalığın yaş ve cinsiyet dağılımına uymaktadır97,99.

EN'nin etyolojisi bölgelere ve ülkelere göre değişiklik gösterebilmektedir 100 . Olguların \%37-60'ında yapılan tüm klinik ve laboratuvar araştırmalarına rağmen etyoloji saptanamamaktadır96,97,101-103

Etyolojisi saptanan olgularda en sık neden infeksiyonlardır (streptokokal infeksiyonlar, derin fungal infeksiyonlar, tüberküloz vb)96,97. Tüm dünyada bölgesel ayrım yapılmaksızın EN'nin etyolojik dağılımı bir bütün olarak ele alındığında, sarkoidozun infeksiyonlardan sonra 2. sırada yer aldığı görülmektedir100-102,104. Bunların dışında inflamatuvar barsak hastalığı, Behçet hastalığı, oral kontraseptifler ve bazı antibiyotikler başta olmak üzere çeşitli ilaçlar veya maligniteler de etyolojide rol almaktadır96,99. Ayrıca literatürde çok sayıda hastalığın da ender olarak EN'ye yol açabileceğinden söz edilmektedir101,102,104. Yukarıda verilen oranlardan anlaşılabileceği gibi eritema nodozum paraneoplastik özelliği düşük bir reaktif dermatozdur. Bununla birlikte sıklıkla lösemi veya lenfoma gibi hematolojik maligniteler olmak üzere çeşitli malignitelerin deri belirtisi olabilmektedir (Tablo 4)105-108. Literatürde pankreas kanseri, kolorektal kanser ve karsinoid tümör gibi bazı malignitelere eşlik eden EN olguları bildirilmiştir106,107. Bu durumlarda klinik ve histolojik bulgular idyopatik ya da diğer nedenlerden kaynaklanan EN'den farklı değildir. Ancak EN'nin tedaviye dirençli olması ve şiddetli seyretmesi altta yatan ciddi bir neden olabileceğini gösteren önemli ipuçlarıdır. EN'li bir hastada herhangi bir malignitenin bulunması etyolojinin açıklanması için yeterli değildir. EN'nin paraneoplastik bir bulgu olarak kabul edilebilmesi için her iki hastalığın eş zamanlı ortaya çıkması, EN'nin diğer sebeplerinin dışlanması ve kanser tedavisinden sonra EN'nin gerilemesi gereklidir109-111

EN malignitelerin öncü lezyonu olabilir, tümörün progresyonu ya da rekürrensinde ortaya çıkabilir veya EN etyolojisi araştırılırken tanı konulabilir109-111. Örneğin geçmişte Hodgkin hastalığı öyküsü olan bir olguda EN'nin ortaya çıkması, hastalığın nüksünü ortaya koyabilir108. Bu nedenle malignite şüphesi duyulduğunda mutlaka ayrıntılı bir araştırma yapılmalıdır96.

Hastalığın tanısında klinik bulgular genellikle yeterli olur, şüpheli olgularda kesin tanı için deri ve deri altı dokusunu içine alan derin insizyonel veya eksizyonel eliptoik deri biyopsisi yapılması önerilmektedir96,97,101,109-111. Tipik olarak vaskülitik septal pannikulit saptanır

EN için belirlenmiş bir tedavi protokolü yoktur ve genellikle 3-6 hafta içinde kendiliğinden iyileşmektedir97. Asıl tedavi, eğer saptandıysa altta yatan nedene yöneliktir. Olguların çoğunda yatak istirahati ve ıslak kompres yeterli olur. Ciddi veya tekrarlayan EN'de aspirin, indometazin, naproksen gibi non-steroid antiinflamatuvar ilaçlar ağrıyı kontrol altına almak için kullanılabilir96. Lezyonlar uzun süre devam ederse potasyum iyodürün faydalı olduğu bildirilmiştir97,121. Sistemik kortikosteroidler nadiren kullanııılar, kullanılmadan önce mutlaka altta yatan olası bir infeksiyonun dışlanması gerekir. Nodülün merkezine yapılan intralezyonel triamsinolon asetonid injeksiyonu da etkili olmaktadır. Bunların dışında kolşisin, hidroksiklorokin ${ }^{121-123}$ siklosporin ve talidomidin ${ }^{124}$ de etkili olduğu bildirilmiştir.

Sonuç olarak; reaktif dermatozların ilişkili olduğu hastalıklar içinde malignitelerin önemli bir yer tuttuğunu vurgulamak istiyoruz. Eritema giratum repens ve nekrolitik migratuvar eritem paraneoplastik ilişkinin daha belirgin olduğu hastalıklar olarak öne çıkmaktadır. Diğerlerinde de malignite ile ilişki olsa da oranları daha düşüktür. Bu dermatozların bazılarında malignitelerin eşlik ettiği olgularda klinik özellikler biraz daha 
farklı olabilmektedir bazılarında ise böyle bir ipucu yoktur. Malignite taraması çok basit bir işlem değildir ve klinik değerlendirmenin yanı sıra birçok ayrıntılı laboratuar ve radyolojik inceleme gerektirir. Dolayısıyla sadece gerektiği durumlarda yapılmalıdır. Altta yatan olası malignite tiplerinin bilinmesi bu incelemeyi önemli ölçüde kolaylaştırır. Bu yazıda reaktif dermatozlara eşlik edebilecek maligniteler, geniş bir literatür taraması ile ayrıntılı olarak incelenerek hastalara yaklaşım konusundaki güncel bilgiler özetlenmeye çalışılmıştır.

\section{Kaynaklar}

1. Sweet RD: An acute febrile neutrophilic dermatosis. $\mathrm{Br}$ J Dermatol 1964;76:349-56.

2. Cohen PR, Kurzrock R: Sweet's syndrome revisited: a review of disease concepts. Int J Dermatol 2003;42:761-78.

3. Cohen PR: Sweet's syndrome-a comprehensive review of an acute febrile neutrophilic dermatosis. Orphanet J Rare Dis 2007;26:2:34.

4. Shapiro L, Baraf CS, Richheimer LL: Sweet's syndrome (acute febrile neutrophilic dermatosis). Report of a case. Arch Dermatol 1971;103:81-4.

5. Strutton G, Weedon $D$, Robertson I: Pustular vasculitis of the hands. J Am Acad Dermatol 1995;32:192-8.

6. Kim MJ, Choe YH: EPONYM. Sweet syndrome. Eur J Pediatr 2010;169:143944.

7. Paydas S: Sweet's syndrome: a revisit for hematologists and oncologists. Crit Rev Oncol Hematol 2013:86:85-95.

8. Bilgili SG, Karadağ AS, Çalka Ö, Bayram I: Sweet sendromu: 31 hastanın klinik ve laboratuar bulgularının değerlendirilmesi. Türkderm 2013;47:33-8

9. Morgan KW, Callen JP: Sweet's syndrome in acute myelogenous leukemia presenting as periorbital cellulitis with an infiltrate of leukemic cells. J Am Acad Dermatol 2001;45:590-5

10. Urano Y, Miyaoka Y, Kosaka M, et al: Sweet's syndrome associated with chronic myelogenous leukemia: demonstration of leukemic cells within a skin lesion. J Am Acad Dermatol 1999;40:275-9.

11. Vignon-Pennamen MD, Juillard C, Rybojad $M$, et al: Chronic recurrent lymphocytic Sweet's syndrome as a predictive marker of myelodysplasia: a report of 9 cases. Arch Dermatol 2006;142:1170-6.

12. Buck T, González LM, Lambert WC, Schwartz RA: Sweet's syndrome with hematologic disorders: a review and reappraisal. Int J Dermatol 2008;47:775-82.

13. Paydas S, Sahin B, Zorludemir S: Sweet's syndrome accompanying leukaemia: seven cases and review of the literature. Leuk Res 2000;24:83-6.

14. Culpa L, Crowderb S, Hatcha S: A rare association of Sweet's syndrome with cervical cancer. Gynecol Oncol 2004;95:396-9.

15. Inomata N, Sasaki T, Nakajima H: Sweet's syndrome with gastric cancer. J Am Acad Dermatol 1999;41:1033-4.

16. Arai $H$, Rino $Y$, Yamanaka $S$, et al: Lung cancer associated with Sweet's syndrome: report of a case. Surg Today 2008;38:639-43.

17. Giménez-Arnau A, Carles J, Pla-Ferrer $C$, et al: Sweet's syndrome and malignancy: a case associated with multiple oral squamous-cell carcinoma. Dermatology 1996;193:154-5.

18. Glendenning J, Khoo V: Sweet's syndrome in prostate cancer. Prostate Cancer Prostatic Dis 2008:11:397-8.

19. Sobol UA, Sherman KL, Smith J, et al: Sweet's syndrome with neurologic manifestations in a patient with esophageal adenocarcinoma: case report and review of the literature. Int I Dermatol 2009;48:1062-5.

20. Roxburgh AC: Annular centrifugal erythema ("Erythème Annulaire Centrifuge," Darier, 1916). Proc R Soc Med 1931;24:1645-6.

21. Yaniv $R$, Shpielberg $O$, Shpiro $D$, et al: Erythema annulare centrifugum as the presenting sign of Hodgkin's disease. Int J Dermatol 1993;32:59-61.

22. Chodkiewicz HM, Cohen PR: Paraneoplastic erythema annulare centrifugum eruption: PEACE. Am J Clin Dermatol 2012;1;13:239-46.

23. Tyritig SK: Reactive erythemas: erythema annulare centrifugum and erythema gyratum repens. Clin Dermatol 1993;11:135-9.

24. Harrison PV: The annular erythemas. Int J Dermatol 1979;18:282-90.

25. White JW Jr: Gyrate erythema. Dermatol Clin 1985;3:129-39.

26. Gündeşlioğlu AO, Ertaş NM, Celebioğlu S, Hücümenoglu S: Erythema annulare centrifugum: an unusual presentation for acute leukemia. Plast Reconstr Surg 2004;113:798-9.

27. Summerly $\mathrm{R}$ : The figúrate erythemas and neoplasia. $\mathrm{Br} J$ Dermatol $1964 ; 76 ; 370-3$
28. Zultak M, Blanc D, Merle C, et al: Erythema annulare centrifugum and acute myeloblastic leukemia. Ann Dermatol Venereol 1989;116;477-80.

29. Helbling I, Walewska R, Dyer MJ, et al: Erythema annulare centrifugum associated with chronic lymphocytic leukaemia. $\mathrm{Br}$ J Dermatol 2007:157:1044-5.

30. Miljkovic J, Bartenjev I: Hypereosinophilic dermatitis-like erythema annulare centrifugum in a patient with chronic lymphocytic leukaemia. J Eur Acad Dermatol Venereol 2005; 19:228-31.

31. Villette $B$, TuUiez M: Erythema annulare centrifugum and Hodgkin's disease. Ann Dermatol Venereol 1990;117;889-90.

32. Carlesimo M, Fidanza L, Mari E, et al: Erythema annulare centrifugum associated with mantle b-cell non-Hodgkin's lymphoma. Acta Derm Venereol 2009;89:319-20.

33. Panasiti $V$, Devirgiliis $V$, Curzio $M$, et al: Erythema annulare centrifugum as the presenting sign of breast carcinoma. J Eur Acad Dermatol Venereol 2009:23:318-20.

34. Ravic-Nikolic A, Milicic V, Jovovic-Dagovic B, Ristic G: Gyrate erythema associated with metastatic tumor of gastrointestinal tract. Dermatol Online J 2006:12:11

35. Monsieur I, Meysman M, Noppen $M$, et al: Non-small-cell lung cancer with multiple paraneoplastic syndromes. Eur Respir J 1995:8:1231-4.

36. Dourmishev LA, Gergovska MJ, Nikolova KK, Balabanova MB: Erythema annulare centrifugum in a patient operated on for breast carcinoma. Acta Dermatovenerol Croat 2010;18:264-6.

37. Dupré $A$, Carrère $A$, Bonafé JL, et al: Erythema annulare centrifugum of the legs symptomatic of prostate adenocarcinoma; a specific paraneoplastic syndrome?. Ann Dermatol Venereol 1979;106:789-92.

38. Murray D, Eady RA: Migratory erythema and eosinophilic cellulitis associated with nasopharyngeal carcinoma. J R Soc Med 1981:74:845-7.

39. Baykal C, Özkaya Gürsoy E: Prolaktinomaya eşlik eden eritem anüler santrifüj. Türkderm 1994:28:46-8.

40. da Silva JA, Mesquita Kde C, Igreja AC, et al: Paraneoplastic cutaneous manifestations: concepts and updates*. An Bras Dermatol 2013;88:9-22.

41. Tierney EP, Badger J: Etiology and pathogenesis of necrolytic migratory erythema: review of the literature. Med Gen Med 2004;10;6:4.

42. Mullans EA, Cohen PR: latrogenic necrolytic migratory erythema: a case report and review of nonglucagonoma-associated necrolytic migratory erythema. J Am Acad Dermatol 1998;38:866-73.

43. Lolis MS, Krishtul A, Vidal C, et al: Necrolytic migratory erythema associated with a metastatic neuroendocrine tumor. Cutis 2011;87:78-80.

44. Dal Coleto CC, de Mello AP, Piquero-Casals J, et al: Necrolytic migratory erythema associated with glucagonoma syndrome: a case report. Rev Hosp Clin Fac Med Sao Paulo 2001;56:183-8.

45. Pipkin CA, Lio PA: Cutaneous manifestations of internal malignancies: an overview. Dermatol Clin 2008:26:1-15.

46. Teixeira RC, Nico MM, Ghideti AC: Necrolytic migratory erythema associated with glucagonoma: a report of 2 cases. Clinics (Sao Paulo) 2008;63:267-70.

47. Alexander EK, Robinson M, Staniec M, Dluhy RG: Peripheral amino acid and fatty acid infusion for the treatment of necrolytic migratory erythema in the glucagonoma syndrome. Clin Endocrinol (Oxf) 2002;57:827-31.

48. Bewley AP, Ross JS, Bunker CB, Staughton RC: Successful treatment of a patient with octreotide-resistant necrolytic migratory erythema. $\mathrm{Br}$ Dermatol 1996;134:1101-4.

49. Ramos-E-Silva M, Carvalho JC, Carneiro SC: Cutaneous paraneoplasia. Clin Dermatol 2011;29:541-7.

50. De La Torre-Lugo EM, Sanchez JL: Erythema gyratum repens. J Am Acad Dermatol 2011:64:89-90.

51. Ehst BD, Minzer-Conzetti K, Swerdlin A, Devere TS: Cutaneous manifestations of internal malignancy. Curr Probl Surg 2010;47:384-445

52. Ersoy Evans S, Karaduman A: Eritemli Dermatozlar. Türk Dermatoloji Dergisi 2009;3:55-62

53. Sneddon IB, Wilkinson DS: Subcorneal pustular dermatosis. Br J Dermatol 1956;68:385-94

54. Cheng S, Edmonds E, Ben-Gashir M, Yu RC: Subcorneal pustular dermatosis: 50 years on. Clin Exp Dermatol 2008;33:229-33.

55. Kasha EE Jr, Epinette WW: Subcorneal pustular dermatosis (SneddonWilkinson disease) in association with a monoclonal IgA gammopathy: a report and review of the literature. J Am Acad Dermatol 1988;19:854-8.

56. Scerri L, Zaki I, Allen BR: Pyoderma gangrenosum and subcorneal pustular dermatosis, without monoclonal gammopathy. $\mathrm{Br}$ J Dermatol 1994;130:398-9.

57. Atukorala DN, Joshi RK, Abanmi A, Jeha MT: Subcorneal pustular dermatosis and IgA myeloma. Dermatology 1993;187:124-6.

58. Brown SJ, Barrett PD, Hendrick A, Langtry JA: Subcorneal pustular dermatosis in association with chronic lymphocytic leukaemia. Acta Derm Venereol 2003;83:306-7. 
59. Villey MC, Ehrsam E, Marrakchi S, et al: Apudoma and subcorneal pustular dermatosis (Sneddon-Wilkinson disease). Dermatology 1992;185:269-71.

60. Buchet $S$, Humbert $P$, Blanc $D$, et al: Subcorneal pustular dermatosis associated with epidermoid carcinoma of the lung. Ann Dermatol Venereol 1991;118:125-8.

61. Yavuz E, Yeșilova Y, Sula B: Paraneoplastik dermatozlar. Haseki Tıp Bülteni 2010;48:61-7

62. Tüzün Y, Maraşoğlu Ö: Pyoderma gangrenosum. J Turk Acad Dermatol 2007:1:71301r

63. Wollina U: Pyoderma gangrenosum-a review. Orphanet J Rare Dis 2007;2:19.

64. Şeremet S, Yüksel Ei, Gürel MS, ve ark: Piyoderma gangrenozum. İstanbul Tip Dergisi 2007;4:49-52.

65. Eichhorn PJ: Pyoderma gangrenosum. Dermatol Ther 2001;14:100-10.

66. Mlika RB, Riahi I, Fenniche $S$, et al: Pyoderma gangrenosum: a report of 21 cases. Int J Dermatol 2002;41:65-8.

67. Serdar ZA, Yaşar Ş, Güneş P: Piyoderma gangrenozum: 20 olgunun retrospektif değerlendirilmesi. Turkderm 2011;45:83-7.

68. Pereira N, Brites MM, Gonçalo M, et al: Pyoderma gangrenosum-a review of 24 cases observed over 10 years. Int J Dermatol 2013;52:938-45.

69. Callen JP: Pyoderma gangrenosum. Lancet 1998;351:581-5.

70. Powell FC, Schroeter AL, Su WP, Perry HO: Pyoderma gangrenosum: a review of 86 patients. Q J Med 1985;55:173-86.

71. Chung VQ, Moschella SL, Zembowicz A, Liu V: Clinical and pathologic findings of paraneoplastic dermatoses. J Am Acad Dermatol 2006;54:74562.

72. Van den Driesch P: Pyoderma gangrenosum: a report of 44 cases with follow-up. Br J Dermatol 1997;137:1000-5.

73. Ruocco E, Sangiuliano S, Gravina AG, et al: Pyoderma gangrenosum: an updated review. J Eur Acad Dermatol Venereol 2009;23:1008-17.

74. Powell FC, Su WP, Perry HO: Pyoderma gangrenosum: classification and management. J Am Acad Dermatol 1996;34:395-409.

75. Wollina U: Clinical management of pyoderma gangrenosum. Am J Clin Dermatol 2002;3:149-58.

76. Schwaegerle SM, Bergfeld WF, Senitzer D, Tidrick RT: Pyoderma gangrenosum: a review. J Am Acad Dermatol 1988;18:559-68.

77. Ahmadi S, Powell FC: Pyoderma gangrenosum: uncommon presentations. Clin Dermatol 2005;23:612-20.

78. Török L, Kirschner A, Gurzó M, Krenács L: Bullous pyoderma gangrenosum as a manifestation of leukemia cutis. Eur J Dermatol 2000;10:463-5.

79. Su WP, Davis MD, Weenig RH, et al: Pyoderma gangrenosum: clinicopathologic correlation and proposed diagnostic criteria. Int J Dermatol 2004; $43: 790-800$

80. Miller J, Yentzer BA, Clark A, et al: Pyoderma gangrenosum: A review and update on new therapies. J Am Acad Dermatol 2010;62:646-54.

81. Wenzel J, Gerdsen R, Phillipp-Dormston W, et al: Topical treatment of pyoderma gangrenosum. Dermatology 2002;205:221-3.

82. Tamir A, Landau M, Brenner S: Topical treatment with $1 \%$ sodium cromoglycate in pyoderma gangrenosum. Dermatology 1996;192:252-4.

83. Sanders CJ, Hulsmans RF: Successful treatment of pyoderma gangrenosum with topical 5-aminosalicylic acid. Cutis 1993;51:262-4.

84. Tsele E, Yu RC, Chu AC: Pyoderma gangrenosum response to topical nitrogen mustard. Clin Exp Dermatol 1992;17:437-40.

85. Conrad C, Trüeb RM: Pyoderma gangrenosum. J Dtsch Dermatol Ges 2005;3:334-42

86. Arbiser JL, Moschella SL: Clofazimine: a review of its medical uses and mechanisms of action. J Am Acad Dermatol 1995:32:241-7.

87. Wollina $U$, Karamfilov $T$ : Treatment of recalcitrant ulcers in pyoderma gangrenosum with mycophenolate mofetil and autologous keratinocyte transplantation on a hyaluronic acid matrix. J Eur Acad Dermatol Venereol 2000:14:187-90.

88. Baumgart DC, Wiedenmann B, Dignass AU: Successful therapy of refractory pyoderma gangrenosum and periorbital phlegmona with tacrolimus [FK506] in ulcerative colitis. Inflamm Bowel Dis 2004;10:421-4

89. Peuckmann V, Fisch M, Bruera E: Potential novel uses of thalidomide: focus on palliative care. Drugs 2000;60:273-92

90. Kontochristopoulos GJ, Stavropoulos PG, Gregoriou S, Zakopoulou $\mathrm{N}$ : Treatment of pyoderma gangrenosum with low-dose colchicine. Dermatology 2004;209:233-6.

91. Sapienza MS, Cohen S, Dimarino AJ: Treatment of pyoderma gangrenosum with infliximab in Crohn's disease. Dig Dis Sci 2004:49:1454-7.
92. Roy DB, Conte ET, Cohen DJ: The treatment of pyoderma gangrenosum using etanercept. J Am Acad Dermatol 2006:54:128-34.

93. Hubbard VG, Friedmann AC, Goldsmith P: Systemic pyoderma gangrenosum responding to infliximab and adalimumab. Br J Dermatol 2005; 152:1059-61.

94. Pastor N, Betlloch I, Pascual JC, et al: Pyoderma gangrenosum treated with anti-TNF alpha therapy (etanercept). Clin Exp Dermatol 2006;31:152-3.

95. Pomerantz RG, Husni ME, Mody E, Qureshi AA: Adalimumab for treatment of pyoderma gangrenosum. Br J Dermatol 2007;157:1274-5.

96. Schwartz RA, Nervi SJ: Erythema nodosum: a sign of systemic disease. Am Fam Physician 2007:75:695-700.

97. Mert A: Eritema nodozum: 9 yillık deneyim. Cerrahpaşa J Med 2002;33:4759

98. Adışen E, Şeker Ü, Gürer MA: Eritema nodozumda etyolojik faktörler Turkderm 2008;42:113-7.

99. Requena L, Yus ES: Erythema nodosum. Dermatol Clin 2008;26:425-38.

100. Passarini B, Infusino SD: Erythema nodosum. G Ital Dermatol Venereol 2013:148:413-7.

101. Garcl'a-Porru'a C, Gonza'lez-Gay MA, Va'zquez-Caruncho M, et al: Erythema nodosum: etiologic and predictive factors in defined population Arthritis Rheum 2000;43:584-92.

102. Cribier B, Caille A, Heid E, Grosshans E: Erythema nodosum and associated diseases: a study of 129 cases. Int J Dermatol 1998;37:667-72.

103. Psychos DN, Voulgari PV, Skopouli FN, et al: Erythema nodosum: the underlying conditions. Clin Rheumatol 2000;19:212-6.

104. Puavilai S, Srõprachaya-Anunt S, Charuwichõtratana S, et al: Etiology of erytema nodosum. J Med Assoc Thai 1995:78:72-5.

105. Sullivan R, Clowers-Webb H, Davis MD: Erythema nodosum: a presenting sign of acute myelogenous leukemia. Cutis 2005;76:114-6.

106. Lin JT, Chen PM, Huang DF, et al: Erythema nodosum associated with carcinoid tumour. Clin Exp Dermatol 2004;29:426-7.

107. Durden FM, Variyam E, Chren MM: Fat necrosis with features of erythema nodosum in a patient with metastatic pancreatic carcinoma. Int J Dermatol 1996:35:39-41.

108. Bonci A, Di Lernia V, Merli F, Lo Scocco G: Erythema nodosum and Hodgkin's disease. Clin Exp Dermatol 2001;26:408-11.

109. Camilleri MJ, Daniel Su WP: Cutaneous T cell lymphomas. Fitzpatrick's Dermatology in General Medicine. Ed. Freedberg IM, Eisen AZ, Wolff K, et al. 6.th ed, New York, The McGraw-Hill Companies, 2003;1047-63.

110. White WL, Hitchcock MG: Diagnosis: erythema nodosum or not? Semin Cutan Med Surg 1999:18:47-55.

111. Tay YK: Erythema nodosum in Singapore. Clin Exp Dermatol 2000;25:377 80

112. Lillo A, Gil MJ, Jimenez R, Monferrer R: Eritema nudoso y adenocarcinoma de colon. Med Clin (Barc) 1997;108:318

113. Altomare GF, Capella GL: Paraneoplastic erythema nodosum in a patient with carcinoma of the uterine cervix. Br J Dermatol 1995;132:667-8.

114. Glinkov S, Krasnaliev I, Atanassova M: Hepatocellular carcinoma associated with paraneoplastic erythema nodosum and polyarthritis. I Hepatol 2003;39:656-7.

115. Reynolds NJ, Kennedy C: Erythema nodosum and cutaneous vasculitis associated with recurrence of Hodgkin's disease. $\mathrm{Br} J$ Dermatol 1990;123:101-2.

116. SuLLivan R, Clowers-Webb H, Davis MD: Erythema nodosum: a presenting sign of acute myelogenous leukemia. Cutis 2005;76:114-6.

117. Perez NB, Bernad B, Narvaez J, Valverde J: Erythema nodosum and lung cancer. Joint Bone Spine 2006:73:336-7.

118. Parodi A, Costari R, Rebora A: Erythema nodosum as the presenting symptom of gastric centrofollicular lymphoma. Int J Dermatol 1989:28:336-7.

119. Weinstein A, Bujak D, Mittelman A, Davidian M: Erythema nodosum in a patient with renal cell carcinoma treated with interleukin 2 and lymphokine-activated killer cells. JAMA 1987;258:3120-1.

120. Hannuksela M: Erythema nodosum. Clin Dermatol 1986:4:88-95.

121. Horio T, Imamura S, Danno K, Ofuji S: Potassium iodide in the treatment of erythema nodosum and nodular vasculitis. Arch Dermatol 1981;117:29-31.

122. Wallace SL: Erythema nodosum treatment with colchicine. JAMA 1967;202:1056

123 Jarret $P$, Goodfield MJ: Hydroxychloroquine and chronic erythema nodosum. Br J Dermatol 1996;134:373.

124. Tremaine WJ: Treatment of erythema nodosum, aphthous stomatitis, and pyoderma gangrenosum in patients with IBD. Inflamm Bowel Dis 1998:4:68-9. 